\title{
ANALISIS CAPITAL ADEQUANCY RATIO (CAR), LOAN TO DEPOSIT RATIO (LDR) DAN RETURN ON ASSETS (ROA) TERHADAP TINGKAT SUKU BUNGA DEPOSITO BERJANGKA PADA BANK BUMN PERIODE 2009-2014
}

\author{
Isna Nurcahyani Suratama \\ Isnanurcahyani30@gmail.com \\ Universitas Ahmad Dahlan \\ Dyah Fitriani \\ Dhifa_dhe@yahoo.com \\ Universitas Ahmad Dahlan
}

\begin{abstract}
ABSTRAK
This study aims to determine the effect of Capital Adequacy Ratio (CAR), Loan to Deposit Ratio (LDR) and Return on Assets (ROA) on the interest rate for time deposits at state-owned banks in Indonesia in the 2009-2014 period. The sample used in this study is state-owned banks in Indonesia, as many as 4 banks. The sampling technique used was purposive sampling technique. The method used in this study is quantitative research and the data obtained are secondary data where the data is already available in report form. The analysis technique used is multiple linear regression, hypothesis testing ( $\mathrm{t}$ test and $\mathrm{F}$ test) and the coefficient of determination test. The results of the analysis showed that partially the Capital Adequacy Ratio (CAR) showed a regression coefficient of -0.674775 with a prob value of 0.5915 , which meant that the CAR had a negative and not significant effect on deposit rates, while the Loan to Deposit Ratio (LDR) showed a value of regression coefficient of 0.109967 with a value of prob. 0.6871 which means that the LDR has a positive and not significant effect on the interest rate on time deposits and Return on Assets (ROA) shows a value of $-10,63718$ with a prob. 0.4255 which means ROA has a negative and not significant effect on the interest rate on time deposits. Based on the $\mathrm{F}$ test shows a prob value of 0.300476 so that simultaneously, CAR, LDR and ROA have no significant effect on the interest rate on time deposits.
\end{abstract}

Keyword: Time Deposit Interest Rates, Capital Adequacy Ratio (CAR), Loan to Deposit Ratio (LDR) and Return on Assets (ROA).

\footnotetext{
PENDAHULUAN

Bank merupakan lembaga keuangan yang memiliki peran penting bagi perekonomian suatu negara. Hal ini bisa dibuktikan dari kegiatan utama bank yaitu penghimpunan dana, penyaluran dan berbagai jasa yang ditawarkan. Kegiatan tersebut sangat membantu kegiatan ekonomi suatu negara serta dapat melancarkan sistem pembayaran bagi semua sektor perekonomian. Dana bank salah satunya diperoleh dari masyarakat
}

dalam bentuk simpanan, seperti giro, tabungan maupun deposito. Bank dapat menggunakan dana tersebut untuk memperoleh keuntungan yaitu dengan menyalurkannya kepada masyarakat yang membutuhkan dalam bentuk kredit. (Setiawan, 2013)

Industri perbankan yang sehat dan efisien adalah lembaga yang menyediakan sumber pembiayaan yang baik bagi pembangunan dengan meningkatkan investasi. Salah satu produk perbankan yang dapat dijadikan alternatif masyarakat untuk beinvestasi adalah Deposito. 
Menurut Undang-Undang No. 10/1998, Pasal 1 ayat 7 (1998, hal. 7) yang memberikan pengertian deposito adalah sebagai berikut: "Deposito adalah simpanan yang penarikannya hanya dapat dilakukan pada waktu tertentu berdasarkan perjanjian nasabah penyimpan dengan bank". Deposito adalah produk simpanan di bank yang penyetoran maupun penarikannya hanya dapat dilakukan pada waktu tertentu saja atau sesuai dengan jatuh temponya sehingga deposito dikenal juga sebagai tabungan berjangka. Daya tarik utama bagi masyarakat adalah bunga yang diberikan oleh bank-bank untuk melakukan kegiatan penyimpanan uang.

Kebanyakan masyarakat memilih deposito sebagai alternatif yang paling baik untuk menyimpan dana yang mereka miliki. Daya tarik masyarakat untuk menyimpan dananya adalah tergantung pada besar kecilnya suku bunga deposito yang ditawarkan oleh suatu bank. Dewasa ini, bank-bank umum seperti halnya bankbank persero sangat menguasai dan mendominasi pasar perbankan terutama untuk produk deposito dalam hal menentukan tingkat bunga dan jumlah deposito yang berhasil dihimpun.

Suku bunga deposito sebagai daya tarik utama bagi masyarakat dalam menghimpun dananya dibank, akan tetapi harus dilakukan secara hati-hati dan teliti karena apabila suku bunga deposito pada suatu bank rendah akan membuat masyarakat justru enggan menabung. Apabila suku bunga terlalu tinggipun akan berdampak pada suku bunga yang secara otomatis menjadi sangat tinggi dan tentu akan menyulitkan suatu bank dalam menyalurkan kreditnya. (Setiawan, 2013).

Seiring dengan banyaknya pilihan bank yang dihadapkan kepada masyarakat dan persaingan yang semakin ketat, maka bank harus memperhatikan pelayanan serta produk yang ditawarkan agar mampu bersaingan dengan bank lainnya. Pelayanan bank yang bagus dan profesional dapat menjadikan andalan bank untuk memikat hati masyarakat agar mau menanamkan investasinya di bank serta membangun loyalitas nasabah. Salah satu produk yang ditawarkan oleh bank adalah deposito. Simpanan deposito dalam Undang-Undang Nomor 10 Tahun 1998 dinyatakan sebagai simpanan yang penarikannya hanya dapat dilakukan pada waktu tertentu berdasarkan perjanjian nasabah penyimpanan dengan bank (Martono, 2010). Tingkat suku bunga deposito yang relatif tinggi dapat menjadi daya tarik bagi masyarakat untuk lebih memilih deposito dibandingkan dengan tabungan, namun dengan tingginya bunga tersebut maka cost of loanable funds pada bank juga akan meningkat

Meningkatnya dana simpanan yang diperoleh hendaknya dapat dimanfaatkan oleh bank secara maksimal. Jangan sampai besarnya dana yang dihimpun nantinya malah merugikan bagi bank karena tidak mampu dimanfaatkan secara benar. Dana yang didapat sudah seharusnya digunakan untuk kegiatan yang menguntungkan bagi bank seperti pemberian kredit. Selain dapat memberikan keuntungan, pemberian kredit juga akan mempengaruhi besarnya loan to deposit ratio (LDR). Dendawijaya (2009) mendefinisikan Loan to deposit ratio adalah rasio antara seluruh jumlah kredit yang diberikan bank dengan dana yang diterima oleh bank. Akan tetapi pemberikan kredit mestinya dilakukan secara hati-hati karena sangat berisiko, jika nantinya terjadi kredit macet atau bad debt akan membuat bank mengalami kesulitan dalam membayar ananya yang diperoleh dari deposan. Oleh sebab itu untuk mengantisipasi terjadinya hal tidak di inginkan sepertinya kredit baermasalah bank harus memenuhi modal minimum bank atau capital adequacy ratio (CAR).

Kecukupan modal merupakan faktor yang penting bagi bank dalam rangka pengembangan usaha dan menampung risiko kerugian. Bank Indonesia menetapkan capital adequacy ratio (CAR) yaitu kewajiban penyediaan modal minimum yang harus selalu dipertahankan oleh setiap bank sebagai 
suatu proporsi tertentu dari total aktiva tertimbang menurut risiko (ATMR) (Budisantoso, 2014). Nilai CAR yang tinggi akan menurunkan tingkat keuntungan bank, ini terjadi karena dana yang seharusnya bisa digunakan untuk memperoleh keuntungan dari penyaluran kredit dialihkan ke CAR untuk memenuhi ketentuan modal minimum bank.

Tujuan utama bank adalah untuk mencari keuntungan. Kemampuan bank dalam menghasilkan laba bisa digambarkan dari return on assets (ROA). Perputaran modal yang lancar merupakan salah satu pencapaian yang diinginkan oleh setiap bank. Karena hal ini mengindikasikan bahwa asset yang dimiliki bisa dimanfaatkan secara efektif dalam rangka memperoleh keuntungan. Sebagian keuntungan nantinya dapat digunakan sebagai tambahan modal, bisa juga dialokasikan ke CAR. Sehingga disinyalir akan mempengaruhi kebijakan bank yang berkaitan dengan penghimpunan dana. (Setiawan, 2013)

\section{Rumusan Masalah}

Berdasarkan uaraian latar belakang diatas, maka dapat diidentifikasi permasalahan penelitian ini adalah sebagai berikut :

1. Apakah ada pengaruh negatif dan signifikan antara capital adequacy ratio (CAR) terhadap tingkat suku bunga deposito berjangka pada bank BUMN di Indonesia?

2. Apakah ada pengaruh negatif dan signifikan antara loan to deposit (LDR) terhadap tingkat suku bunga deposito berjangka pada bank BUMN di Indonesia?

3. Apakah ada pengaruh negatif dan signifikan antara return on assets (ROA) terhadap tingkat suku bunga deposito berjangka pada bank BUMN di Indonesia?

4. Apakah ada pengaruh dan signifikan antara capital adequacy ratio (CAR), loan to deposit ratio $(L D R)$ dan return on assets (ROA) secara bersama-sama terhadap tingkat suku bunga deposito berjangka pada bank BUMN di Indonesia?

\section{REVIEW LITERATUR DAN HIPOTESIS}

\section{Landasan Teori}

Pengertian Bank dan Perbankan

Perbankan adalah segala sesuatu yang berkaitan dengan bank, mencakup kelembagaan, kegiatan usaha, serta cara dan proses dalam melaksanakan kegiatan usahanya. Kegiatan usaha tersebut adalah menyangkut jasa keuangan. Dalam perspektif ilmu keuangan, perbankan adalah bagian dari ilmu keuangan (Taswan 2010).

\section{Jenis Bank}

Jenis bank dapat digolongkan menjadi beberapa klasifikasi. Adapun klasifikasi menurut Suyatno, dkk (2005) adalah:

a. Dilihat dari Segi Fungsinya

1. Bank Sentral (Central Bank) adalah Bank Indonesia sebagaimana dimaksud dalam Undang-Undang Dasar 1945 dan yang didirikan berdasarkan Undang-Undang No. 13/1968.

2. Bank Umum (Commercial Bank) adalah yang dalam pengumpulan dananya menerima simpanan dalam bentuk giro dan deposito dan dalam usahanya terutama memberikan kredit jangka pendek.

3. Bank Tabungan (Saving Bank) adalah bank yang dalam pengumpulan dananya menerima simpanan dalam bentuk tabungan dalam usahanya terutama memperbungakan dananya dalam kertas berharga.

4. Bank Pembangunan (Development Bank) adalah bank yang dalam pengumpulan dananya terutama menerima simpanan dalam bentuk deposito dan atau mengeluarkan kertas berharga jangka menengah dan panjang, serta dalam usahanya 
terutama memberikan kredit jangka menengah dan panjang di bidang pembangunan.

5. Bank Desa (Rural Bank) adalah bank yang menerima simpanan dalam bentuk uang dan natura (padi, jagung, dan sebagainya) dan dalam bentuk natura kepada sektor pertanian dan pedesaan.

b. Dilihat dari Segi Kepemilikannya

1. Bank Milik Negara, adalah bank yang modalnya sebagian besar atau keseluruhan modalnya berasal dari negara.

2. Bank Milik Pemerintah Daerah, adalah bank yang modalnya sebagaian besar atau keseluruhannya berasal dari pemerintah daerah.

3. Bank Milik Swasta, adalah bank yang modalnya sebagaian besar atau keseluruhannya berasal dari perorangan atau swasta. Bank milik swasta dapat dibagi menjadi tiga yaitu :bank milik swasta nasional, bank milik swasta asing dan kerjasama antara bank swasta nasional dengan swasta asing.

4. Bank Koperasi, adalah bank yang modalnya berasal dari perkumpulan-perkumpulan koperasi.

c. Dilihat dari Segi Penciptaan Uang Giral

1. Bank Primer, adalah bank yang dapat menciptakan uang giral. Bentuk dari uang giral sendiri dapat berupa cek ataupun giro.

2. Bank Sekunder, adalah bank yang bertugas sebagai perantara dalam menyalurkan kredit. Bank yang tergolong dalam bank sekunder adalah bank tabungan dan bank-bank yang tidak menciptakan uang giral.

\section{Jenis-Jenis Deposito}

Menurut Rivai, dkk (2007) terdapat berbagai jenis deposito, yaitu:

a. Deposito Berjangka

Deposito berjangka adalah simpanan pihak ketiga (rupaih dan valuta asing) yang diterbitkan atas nama nasabah pada bank yang penarikannya hanya dapat dilakukan pada waktu tertentu menurut perjanjian antara penyimpan dengan bank yang bersangkutan.

b. Sertifikat Deposito

Sertifikat deposito atau negotiable certificate of deposits atau sering disingkat dengan $\mathrm{CD}$ adalah deposito berjangka yang bukti simpanannya dapat diperdagangkan atau surat berharga atas unjuk rupiah yang merupakan surat pengakuan utang dari bank dan lembaga keuangan bukan bank yang dapat diperjualbelikan dalam pasar uang.

c. Deposit on Call

Deposit on Call adalah simpanan atas nama (atau pihak ketiga bukan bank) dalam jumlah yang besar, tetap berada dibank selama deposan belum menggunakannya, dan penarikannya hanya dapat dilakukan dengan syarat pemberitahuan sebelumnya.

\section{Penerima Setoran Deposito}

Kuncoro dan Suhardjono (2002) Setoran deposito dapat digunakan dengan banyak cara, yaitu:

a. Setoran tunai, yaitu nasabah melakukan setoran dengan cara mengisi aplikasi/formulir setoran dan menyerahkannya kepada teller bank beserta uangnya.

b. Setoran dengan warkat bank yang bersangkutan, yaitu nasabah melakukan setoran dengan cara mengisi formulir setoran dan menyerahkan kepada teller beserta warkat bank tersebut.

c. Setoran dengan warkat bank lain, yaitu nasabah melakukan setoran dengan cara mengisi formulir setoran 
dan menyerahkan kepada teller beserta warkat bank lain tersebut.

\section{Suku Bunga Deposito}

Bunga simpanan termasuk bunga pada deposito ditawarkan oleh bank untuk mendorong masyarakat agar mau menanamkan dananya di bank. Inilah biaya yang harus dikeluarkan oleh bank atas dana yang dihimpunnya atau biasa disebut dengan cost of laoanable funds.

\section{Penarikan Bunga dan Pokok Deposito}

Pembayaran bunga dan pokok deposito dilakukan pada saat jatuh tempo, yaitu sesuai dengan perjanjian yang telah disepakati anatara bank dengan nasabah. Jika nasabah mengambilnya sebelum saat jatuh tempo maka nasabah mengambilnya sebelum saat jatuh tempo maka nasabah akan dikenakan penalty rate. Biasanya bank menetapkan penalty rate sebesar 1 sampai 3 persen dari nominal pokok deposito.

\section{Analisis Kinerja Bank}

\section{1) Analisis Rasio Likuiditas}

Analisis rasio likuiditas adalah analisis yang dilakukan terhadap kemampuan bank dalam memenuhi kewajiban jangka pendeknya atau kewajiban yang sudah jatuh tempo.

Beberapa rasio likuiditas yang sering dipergunakan dalam menilai kinerja suatu bank antara lain adalah sebagai berikut:

\section{a. Cash Ratio}

Menurut Dendawijaya (2009) Cash Ratio adalah rasio likuid terhadap dana pihak ketiga yang dihimpun bank harus segera dibayar. Rasio ini digunakan untuk mengukur kemampuan bank dalam membayar kembali simpanan nasabah (deposan) pada saat ditarik dengan menggunakan alat likuid yang dimiliki.

\section{b. Reserve Requirement}

Reserve Requirement atau lebih dikenal juga dengan likuiditas wajib minimum adalah suatu simpanan yang wajib dipelihara dalam bentuk giro di Bank Indonesia bagi semua bank.

\section{c. Loan to Deposit Ratio (LDR)}

Dendawijaya (2009) Loan to Deposit Ratio adalah rasio antara seluruh jumlah kredit yang diberikan bank dengan dana yang diterima oleh bank. Menurut Dendawijaya (2009), semakin tinggi rasio tersebut memberikan indikasi semaikn rendahnya kemampuan likuiditas bank yang bersangkutan. Hal ini disebabkan karena jumlah dana yang diperlukan untuk membiayai kredit menjadi semakin besar.

d. Loan to Asset Ratio

Loan to Asset Ratio adalah rasio yang digunakan untuk mengukur tingkat likuiditas bank yang menunjukan kemampuan bank untuk memenuhi permintaan kredit dengan menggunakan total asset yang dimiliki bank.

e. Rasio Kewajiban Bersih Call Money

Persentase dari rasio ini menunjukkan besarnya kewajiban bersih call money terhadap aktiva lancar atau aktiva yang paling likuid dari bank.

\section{2) Analisis Rasio Rentabilitas}

Analisis rasio rentabilitas bank adalah alat untuk menganalisis atau mengukur tingkat efisiensi usaha dan profitabilitas yang dicapai oleh bank yang bersangkutan.

a. Return on Assets (ROA)

Menurut Dendawijaya (2009) Return on Assets adalah rasio ini digunakan untuk mengukur kemampuan manajemen bank dalam memperoleh keuntungan (laba) secara keseluruhan. Semakin besar ROA suatu bank, semakin besar pula tingkat keuntungan yang dicapai bank tersebut dan semaikn baik pula posisi bank tersebut dari segi penggunaan aset.

b. Return on Equity (ROE)

ROE adalah perbandingan antara laba bersih bank dengna ROE modal sendiri. Rasio ROE ini merupakan indikator yang amat penting bagi para 
pemegang saham dan calon investor untuk mengukur kemampuan bank dalam memperoleh laba bersih yang berkaitan dengan pembayaran dividen.

c. Rasio Maya (Beban) Operasional

Rasio biaya operasional adalah pembanding antara biaya operasional dan pendapatan operasional. Rasio biaya operasional digunakan untuk mengukur tingkat efisiensi dan kemampuan bank dalam melakukan kegiatan operasinya.

d. Net Profit Margin (NPM) Ratio

Net profit margin adalah rasio yang menggambarkan tingkat keuntungan (laba) yang diperoleh bank dibandingkan dengan pendapatan yang diterima dari kegiatan operasionalnya.

\section{3) Analisis Rasio Solvabilitas}

\section{a. Capital Adequacy Ratio (CAR)}

Capital adequacy ratio adalah rasio yang mengukur kemampuan bank dalam permodalan untuk mengantisipasi terjadinya kerugian pada aktiva-aktiva yang mngandung risiko. Bank Indonesia mewajibkan setiap bank umum menyediakan modal minimum sebesar $8 \%$ dari total aktiva tertimbang menurut risiko (ATMR).

Menurut Budisantoso (2014), apabila CAR suatu bank terlalu rendah maka kemampuan bank tersebut untuk survive pada saat mengalami kerugian juga rendah. Modal sendiri akan dengan cepat habis untuk menutup kerugian, dan ketika kerugian telah melebihi modal sendiri maka kemampuan bank tersebut untuk memenuhi kewajiban kepada masyarakat menjadi sangat dirugikan.

\section{b. Debt to Equity Ratio}

Debt to Equity Ratio adalah rasio yang digunakan untuk mengukur kemampuan bank dalam menutup sebagian atau seluruh utang-utangnya, baik jangka panjang maupun jangka pendek, dengan dana yang berasal dari modal bank sendiri.

c. Long Term Debt to Assets Ratio

Rasio ini digunakan untuk mengukur seberapa jauh nilai seluruh aktiva bank dibiayai atau dananya diperoleh dari sumber-sumber utang jangka panjang.

\section{Penelitian Terdahulu}

Dewi (2012) dalam penelitiannya yang berjudul analisis pengaruh capital adequacy ratio $(C A R)$, loan to deposit ratio ( $L D R)$ dan return on assets (ROA) terhadap tingkat suku bunga deposito berjangka pada Bank Centra Asia, Tbk Tahun 2001-2010). Berdasarkan uji parsial dalam penelitiannya maka diperoleh hasil bahwa CAR berpengaruh negatif dan tidak signifikan terhadap tingkat suku bunga deposito, kemudian LDR berpengaruh positif dan tidak signifikan terhadap tingkat suku bunga deposito dan ROA berpengaruh negatif dan signifikan terhadap tingkat suku bunga deposito.

Lestari (2008) dalam penelitiannya yang berjudul pengaruh capital adequacy ratio, return on assets dan loan to deposit ratio terhadap suku bunga deposito berjangka pada bank BUMN di Indonesia periode 2002- 2006. Berdasarkan uji parsial maupun simultan dalam penelitiannya diperoleh hasil bahwa CAR, ROA, dan LDR tidak mempunyai pengaruh yang signifikan terhadap suku bunga deposito berjangka. Nugroho (2010) dalam penelitiannya yang berjudul analisis faktorfaktor yang mempengaruhi tingkat suku bunga deposito berjangka pada bank umum di Indonesia tahun 2006-2008. Berdasarkan uji parsial dalam penelitiannya ROA berpengaruh secara negatif dan signifikan terhadap penetapan suku bunga deposito, kemudian LDR tidak berpengaruh secara positif terhadap penetapan suku bunga deposito, kemudian LDR tidak berpengaruh secara positif terhadap penetapan suku bunga deposito dan CAR tidak berpengaruh secara positif terhadap penetapan suku bunga deposito. 
Setiawan (2013) dalam penelitiannya yang berjudul pengaruh Capital Adequacy Ratio (CAR), Loan to Deposit Ratio (LDR) dan Return on Assets (ROA) terhadap tingkat suku bunga deposito berjangka pada bank BUMN periode 2002-2012. Berdasarkan uji parsial dalam penelitiannya diperoleh bahwa CAR berpengaruh negatif dan tidak signifikan terhadap tigkat suku bunga deposito, LDR berpengaruh negatif dan signifikan terhadap tingkat suku bunga deposito, ROA berpengaruh negatif dan signifikan terhadap tingkat suku bunga deposito sedangkan secara simultan CAR, LDR dan ROA berpengaruh signifikan terhadap tingkat suku bunda deposito.

\section{Hipotesis}

H1: Ada pengaruh negatif dan siginfikan antara capital adequacy ratio (CAR) terdapat tingkat suku bunga deposito berjangka pada bank BUMN di Indonesia

$\mathrm{H} 2$ : Ada pengaruh negatif dan signifikan antara loan to deposit ratio (LDR) terhadap tingkat suku bunga deposito berjangka pada bank BUMN di Indonesia.

H3: Ada pengaruh negatif dan signifikan antara return on assets (ROA) terhadap tingkat suku bunga deposito berjangka pada bank BUMN di Indonesia.

H4: Ada pengaruh dan signifikan antara capital adequacy ratio (CAR), loan to deposit ratio $(L D R)$ dan return on assets (ROA) secara bersama-sama terhadap suku bunga deposito berjangka pada bank BUMN di Indonesia.

\section{METODE PENELITIAN}

\section{Populasi dan Sampel}

Sanusi (2011) Populasi adalah seluruh kumpulan elemen yang menunjukan ciri-ciri tertentu yang dapat digunakan untuk membuat kesimpulan. Jadi, kumpulan elemen itu menunjukkan jumlah, sedangkan ciri-ciri tertentu menunjukkan karakteristik dari kumpulan itu. Populasi yang digunakan dalam penelitian ini adalah bank BUMN yang ada di Indonesia.

Sampel yang digunakan dalam penelitian ini adalah 4 bank BUMN yaitu Bank Mandiri, Bank Rakyat Indonesia, Bank Negara Indonesia, dan Bank Tabugan Negara. Sampel diambil dengan menggunakan teknik purposive sampling. Teknik purposive sampling adalah teknik penentuan sampel berdasarkan atas kriteria-kriteria tertentu.

\section{Definisi Operasional}

1. Variabel Independen

Variabel independen atau bebas merupakan variabel yang mempengaruhi terhadap variabel dependen. Dalam penelitian ini yang merupakan variabel independen adalah sebagai berikut:

a. Capital Adequacy Ratio

CAR adalah rasio yang memperlihatkan seberapa jauh seluruh aktiva bank yang mengandung risiko (kredit, penyertaan, surat berharga, tagihan pada bank lain) ikut dibiayai dari dana modal sendiri bank disamping memperoleh dana-dana dari sumbersumber di luar bank, seperti dana masyarakat, pinjaman (utang), dan lain-lain. Dengan kata lain, capital adequacy ratio adalah rasio kinerja bank untuk mengukur kecukupan modal yang dimiliki bank untuk menunjang aktiva yang mengandung atau menghasilkan risiko, misalnya kredit yang diberikan. (Dendawijaya, 2009).

Rasio ini dapat dirumuskan sebagai berikut :

$\mathrm{CAR}=\frac{\text { Modal Bank }}{\text { Aktiva Tertimbang Menurut Risiko }} \times 100 \%$

\section{b. Loan to Deposit Ratio}

LDR adalah rasio antara seluruh jumlah kredit yang diberikan bank dengan dana yang 
diterima oleh bank. Rasio ini menunjukkan salah satu penilaian likuiditas bank dan dapat dirumuskan sebagai berikut :

$L D R=\frac{\text { Jumlah Kredit yang Diberikan }}{\text { Total dana Pihak Ketiga }+K L B I+\text { Modal Inti }} \times 100 \%$

\section{c. Return on Assets}

Rasio ini digunakan untuk mengukur kemampuan manajemen bank dalam memperoleh keuntungan (laba) secara keseluruhan. Semakin besar ROA suatu bank, semakin besar pula tingkat keuntungan yang dicapai bank tersebut dan semakin baik pula posisi bank tersebut dari segi penggunaan aset. Rasio ini dapat dirumuskan:

$$
\text { ROA }=\frac{\text { Laba bersih } \times 100 \%}{\text { Total aktiva }} \times 100 \%
$$

\section{Variabel Dependen}

Variabel dependen atau terikat merupakan variabel yang dipengaruhi oleh variabel independen. Dalam penelitian ini yang merupakan variabel dependen adalah tingkat suku bunga berjangka 12 bulan. Tingkat suku bunga berjangka dinyatakan dalam bentuk persentase dan digunakan untuk menarik masyarakat agar menginvestasikan dananya di bank.

\section{Teknik Analisis Data}

1. Analisis Regresi Linier Berganda Suliyanto (2008) Analisis regresi digunakan untuk mengukur kekuatan hubungan antara dua variabel atau lebih, juga digunakan untuk menunjukan arah hubungan antara variabel bebas dengan variabel untungnya. Dengan menggunakan analisis regresi akan diperoleh koefisien untuk setiap variabel bebasnya. Dengan diperolehnya koefisien regresi maka diharapkan akan dapat diperoleh nilai variabel tergantung yang mampu meminimumkan penyimpangan.

Pada penelitian ini yang digunakan adalah analisis regresi linier berganda karena terdapat lebih dari satu variabel independen. Model analisisnya adalah sebagi berikut:

$$
\begin{array}{ll}
\begin{array}{ll}
\mathrm{Y}=\alpha+\beta \\
\mathrm{Y}
\end{array} & \mathrm{X}_{1}+\beta 2 \mathrm{X}_{2}+\beta 3 \mathrm{X}_{3}+\varepsilon \\
\alpha & =\text { Tingkat suku bunga deposito berjangka } \\
\mathrm{X}_{1} & =\text { Capital Adequacy Ratio } \\
\mathrm{X}_{2} & =\text { Loan to Deposit Ratio } \\
\mathrm{X}_{3} & =\text { Return on Assets } \\
\beta 1, \beta 2, \beta 3 & =\text { Koefisien Regresi } \\
\varepsilon & =\text { Error Term }
\end{array}
$$

\section{Uji Asumsi Klasik}

a. Uji Normalitas

Uji Normalitas dimaksudkan untuk mengetahui apakah residual yang telah distandarisasi berdistribusi normal atau tidak (Sulisyanto, 2008).

\section{b. Uji Autokorelasi}

Salah satu asumsi dalam analisis regresi linier dengan OLS (ordinary least square) adalah tidak adanya masalah autokorelasi. Autokorelasi adalah hubungan antara residual satu observasi dengan observasi lainnya $[\mathrm{E}(\mathrm{ei}, \mathrm{ej}) \neq 0$ dan $\mathrm{i} \neq \mathrm{j}]$. Setiap data residual pada autokorelasi $[E(e i, e j) \neq 0$ dan $i \neq j]$. Autokorelasi lebih mudah terjadi pada data yang sifatnya runtut waktu (time series), karena sifat datanya yang biasanya dipengaruhi oleh data sebelumnya. Autokorelasi juga dimungkinkan terjadi pada data antar objek (cross section). Autokorelasi dapat berbentuk positif dan negatif. Autokorelasi pada regresi linier dapat menyebabkan terjadinya kebiasan pada kesimpulan yang diambil.

c. Uji Heteroskedastisitas

$$
\text { Ismanto dan Desta (2012) }
$$

Heteroskedastisitas adalah kondisi dimana 
nilai varians error untuk setiap data pengamatan tidak konstan atau var (ei) = 2. Salah satu asumsi dalam model regresi dengan OLS adalah nilai error atau residual memiliki varians yang konstan var (ei) $=2$ atau disebut juga homoskedastisitas. Pada kenyataannya nilai residual sulit memiliki varian konstan, yang membuat nilai taksiran varaians dan standar error koefisien regresi menjadi tidak efisien (underestimate) sehingga pengujian hipotesis dengan uji $\mathrm{t}$ menjadi tidak valid (overestimate). Heteroskedastisitas sering dijumpai pada data yang sifatnya cross section daripada time series. Dalam penelitian yang menyangkut data keuangan perusahaan misalnya, akan terjadi perbedaan yang cukup besar antara perusahaan besar dan perusahaan kecil.

\section{d. Uji Multikolinearitas}

Ismanto dan Desta (2012)

Multikolinearitas merupakan salah satu masalah dalam analisis regresi OLS, yang berarti terdapat korelasi atau hubungan yang sangat tinggi diantara variabel independen.Multikolinearitas hanya terjadi pada regresi majemuk, karena melibatkan beberapa variabel independen sehingga tidak terjadi pada regresi sederhana.

\section{Uji Hipotesis}

\section{Uji Parsial (Uji T)}

Uji t digunakan untuk mengetahui pengaruh antara variabel independen dengan variabel dependen secara parsial. Pada penelitian ini uji $t$ digunakan untuk mengetahui pengaruh secara parsial atau sendiri-sendiri antara CAR, LDR, dan ROA terhadap tingkat suku bunga deposito berjangka pada bank BUMN di Indonesia.

Dasar pengambilan keputusannya dengan menggunakan program Eviews adalah sebagai berikut :

a) Apabila nilai probabilitas $<0,05$ maka Ha diterima b) Apabila nilai probabilitas $>0,05$ maka Ha ditolak

\section{Uji Simultan (Uji F)}

Uji $F$ digunakan untuk mengetahui pengaruh antara variabel independen dengan variabel dependen secara simultan atau bersamasama. Pada penelitian ini uji $\mathrm{F}$ digunakan untuk mengetahui pengaruh secara simultan atau bersama-sama antara CAR, LDR, dan ROA terhadap tingkat suku bunga deposito berjangka pada bank BUMN di Indonesia.

Dasar pengambilan keputusan dengan menggunakan program Eviews adalah sebagai berikut :
a) Apabila nilai probablilitas $<0,05$ maka Ha diterima
b) Apabila nilai probablilitas > 0,05 maka Ha ditolak.

\section{Uji Koefisien Determinasi}

Koefisien determinasi adalah ukuran yang menunjukkan besarnya variasi variabel dependen yang dapat dijelaskan (explained) oleh persamaan (model) yang diperoleh. Didalam suatu persamaan regresi, koefisien determinasi menunjukkan persentase pengaruh semua variabel independen yang terdapat didalam persamaan terhadap variabel dependennya.

\section{HASIL PENELITIAN DAN PEMBAHASAN}

\section{Statistik Deskriptif}

Statistik deskriptif bertujuan untuk memberikan gambaran pada data-data variabel penelitian. Deskripsi variabel yang digunakan dalam penelitian ini meliputi nilai minimum, maksimum, mean dan standar deviasi dari tiga variabel independen yaitu CAR (Capital Adequacy Ratio), LDR (Loan to Deposit Ratio) dan ROA (Return On Assets) sebagai variabel yang mempengaruhi tingkat suku bungadeposito berjangka. Perhitungan data 
deskriptif dapat dilihat pada tabel 4.2 sebagai berikut :

Tabel 4.2 Statistik Deskriptif Variabel Penelitian

\begin{tabular}{|l|c|c|c|c|}
\hline & SUKU_BUNGA & CAR & LDR & ROA \\
\hline Mean & 7.013333 & 16.01708 & 83.31333 & 3.178750 \\
\hline Median & 6.905000 & 15.55000 & 81.28000 & 3.385000 \\
\hline Maximum & 9.400000 & 21.54000 & 108.0000 & 5.150000 \\
\hline Minimum & 5.910000 & 13.20000 & 59.15000 & 1.120000 \\
\hline Std. Dev. & 1.174389 & 1.907843 & 14.12830 & 1.181099 \\
\hline \multicolumn{5}{|c|}{ Sumber : Data Sekunder di olah 2015 } \\
\hline
\end{tabular}

Dari analisis deskriptif di atas dapat disimpulkan bahwa dari 4 sampel data maka variabel CAR memiliki nilai minimum sebesar 13.20000 dan nilai maksimum sebesar 21.54000. Sedangkan nilai ratarata sebesar 16.01708 dengan standar deviasi sebesar 1.907843. Standar deviasi yang lebih kecil dari rata-rata menunjukkan simpangan data yang rendah, ini menunjukkan bahwa data variabel CAR mengindikasikan hasil yang baik. Dengan demikian hal ini menunjukkan bahwa nilai CAR yang dimiliki oleh bank-bank tersebut semuanya sudah memenuhi standar yang ditentukan oleh Bank Indonesia, yaitu sebesar 8\%.

Hasil analisis deskriptif pada variabel LDR memiliki nilai minimum sebesar 59.15000dan nilai maksimum sebesar 108.0000. Sedangkan nilai rata-rata sebesar 83.31333 dengan standar deviasi sebesar 14.12830. Nilai standar deviasi yang lebih rendah dari rata-rata menunjukkan bahwa data variabel LDR mengindikasi hasil yang baik.

Pada variabel ROA memiliki nilai minimum sebesar 1.120000 dan nilai maksimum 5.150000. Sedangkan nilai rata-rata sebesar 3.178750 dengan nilai standar deviasi sebesar 1.181099. Nilai ini sama seperti pada CAR dan LDR karena standar deviasi lebih kecil dari rata-rata sehingga menunjukkan simpangan data yang rendah, oleh karena itu variabel ROA mengindikasi hasil yang baik.

Variabel tingkat suku bunga deposito memiliki nilai minimum sebesar 5.910000 dan nilai maksimum sebesar 9.400000 . Sedangkan nilai rata-rata sebesar 7.013333 dengan standar deviasi sebesar 1.174389.
Hal ini menunjukkan bahwa variabel suku bunga deposito mengindikasi hasil yang baik seperti variabel independen yaitu CAR, LDR, dan ROA karena standar deviasi lebih kecil dari pada nilai rata-rata.

\section{Uji Asumsi Klasik}

1. Uji Normalitas

Tabel 4.4 Hasil Uji Jarque-Bera

\begin{tabular}{|c|c|c|}
\hline Jarque-Bera & Probability & Keterangan \\
\hline 4.246831 & 0.119622 & Prob. $>0,05$ \\
\hline \multicolumn{2}{|l}{ Sumber : Data Sekunder Diolah 2015}
\end{tabular}

Berdasarkan hasil uji Jarque-Bera terlihat nilai Jarque-Bera 4.246831 sebesar dengan prob. Sebesar 0.119622, hasil ini menunjukkan bahwa data berdistribusi normal, karena prob. J-B >0,05.

\section{Uji Autokorelasi}

Tabel 4.5 Hasil Uji Breusch-Godfrey

\begin{tabular}{|l|c|l|c|}
\hline F-statistic & 0.662531 & Prob.F(2,18) & 0.5277 \\
\hline Obs*R-squared & 1.645608 & Prob.Chi-Square(2) & 0.4392 \\
\hline \multicolumn{2}{|l|}{} & \\
\hline
\end{tabular}

Berdasarkan hasil uji Breush-Godfrey pada tabel diatas diketahui bahwa nilai prob. Chi Square sebesar 0.4392 yang lebih besar dari 0.05 (prob. Chi Square > $0,05)$, sehingga dapat disimpulkan tidak terjadi masalah autokorelasi.

\section{Uji Heteroskedastisitas}

Tabel 4.6 Hasil Uji White

\begin{tabular}{|c|c|c|c|}
\hline F-statistic & 1.837666 & Prob. F(9,14) & 0.1483 \\
\hline Obs*R-squared & 12.99767 & Prob. Chi-Square (9) & 0.1627 \\
\hline Scaled explained SS & 10.90008 & Prob. Chi-Square (9) & 0.2826 \\
\hline \multicolumn{3}{|l}{} & \\
\hline
\end{tabular}

Tabel 4.7 Hasil Uji Breush-Pagan-Godfrey (BPG)

\begin{tabular}{|l|c|l|c|}
\hline F-statistic & 0.592424 & Prob. F (3,20) & 0.6272 \\
\hline Obs*R-squared & 1.958670 & Prob. Chi-Square (3) & 0.5810 \\
\hline Scaled explained SS & 1.642576 & Prob. Chi-Squared (3) & 0.6498 \\
\hline \multicolumn{2}{|l}{} & & \\
\hline
\end{tabular}

Dari hasil pemeriksaan terhadap gejala heteroskedastisitas dengan uji White dan Uji BPG tersebut menunjukkan masing-masing nilai Prob. Chi-Square pada Obs*R-Squared lebih besar daripada 0.05. Jadi, dalam kasus ini terlihat tidak adanya masalah heteroskedastisitas. 


\section{Uji Multikolineiritas}

Tabel 4.8 Hasil Uji Multikolinearitas

\begin{tabular}{|c|c|c|c|}
\hline & CAR & LDR & ROA \\
\hline CAR & 1.000000 & 0.265898 & -0.146871 \\
\hline LDR & 0.265898 & 1.000000 & -0.443900 \\
\hline ROA & -0.146871 & -0.443900 & 1.000000 \\
\hline
\end{tabular}

Pada pengujian korelasi antar variabel independen diatas terlihat tidak adanya nilai korelasi (derajat keeratan) yang sangat tinggi $(<90 \%)$ anatarvariabel independen. Hal ini menunjukkan tidak adanya gejala multikolinearitas.

\section{Analisis Regresi Berganda Tabel 4.9 Hasil Uji Regresi Linier Berganda}

\begin{tabular}{|c|c|}
\hline Variable & Coefficient \\
\hline C & 46.05936 \\
\hline CAR & -0.674775 \\
\hline LDR & 0.109967 \\
\hline ROA & -10.63718 \\
\hline
\end{tabular}

Sumber : Data Sekunder Diolah 2015

Dari tabel diatas,dapat diperoleh persamaan regresi linier berganda sebagai berikut :

$\mathrm{Y}=46.05936-0.674775 \mathrm{X} 1+0.109967 \mathrm{X} 2-$ $10.63718 \times 3+\varepsilon$

Dimana :

$\mathrm{Y}=$ Tingkat Suku Bunga Deposito

X1 = Capital Adequacy Ratio (CAR)

$\mathrm{X} 2=$ Loan to Deposit Ratio (LDR)

$\mathrm{X} 3=$ Return on Assets (ROA)

$\varepsilon=$ Error Term

Penjelasan untuk masing-masing variabel yang terdapat pada tabel diatas adalah sebagai berikut :

a. Nilai koefisien konstanta 46.05936 mempunyai makna apabila semua variabel independen diasumsikan sama dengan nol (0), maka Y adalah 46.05936. Berdasarkan hasil tersebut berarti apabila CAR, LDR dan ROA nilainya nol, maka besarnya tingkat suku bunga deposito berjangka adalah 46.05936 .

b. Untuk variabel CAR, diperoleh nilai koefisien sebesar -0.674775 dengan tanda negatif yang berarti bahwa pada tahun 2009 sampai dengan 2014 kenaikan CAR (Capital Adequacy Ratio) akan menyebabkan penurunan suku bunga deposito 12 bulan pada bank BUMN. Nilai tersebut berarti bahwa setiap penurunan 1 CAR akan menyebabkan penurunan suku bunga deposito sebesar -0.674775 .

c. Untuk variabel LDR, diperoleh nilai koefisien sebesar 0.109967 dengan tanda positif yang berarti bahwa pada tahun 2009 sampai dengan 2014 kenaikan LDR (Loan to Deposit Ratio) akan menyebabkan penurunan suku bunga deposito berjangka 12 bulan pada bank BUMN. Nilai tersebut berarti bahwa setiap kenaikan 1 nilai LDR akan menyebabkan kenaikan suku bunga deposito berjangka sebesar 0.109967 .

d. Untuk variabel ROA, diperoleh nilai koefisien sebesar -10.63718 dengan tanda negatif yang berarti bahwa pada tahun 2009 sampai dengan 2014 kenaikan ROA (Return on Assets) akan menyebabkan penurunan suku bunga bunga deposito berjangka 12 bulan pada bank BUMN. Nilai tersebut berarti bahwa setiap penurunan 1 nilai ROA akan menyebabkan penurunan suku bunga deposito berjangka sebesar -10.63718 . 
Tabel 4.10 Hasil Uji t

\begin{tabular}{|c|c|}
\hline Variable & Prob. \\
\hline C & 0.3242 \\
\hline CAR & 0.5915 \\
\hline LDR & 0.6871 \\
\hline ROA & 0.4255 \\
\hline
\end{tabular}

Sumber : Data Sekunder Diolah 2015

Berdasarkan tabel diatas dapat disimpulkan:

a. Uji hipotesis 1

Hasil pengujian variabel CAR menunjukkan bahwa diperoleh nilai koefisien regresi sebesar -0.674775 dengan nilai prob. Sebesar 0.5915 . Karena nilai prob. lebih besar dari 0.05 , maka secara parsial variabel CAR berpengaruh negatif dan tidak signifikan terhadap tingkat suku bunga deposito berjangka, hal ini berarti bahwa Ha1 ditolak.

b. Uji hipotesis 2

Hasil pengujian variabel LDR menunjukkan bahwa diperoleh nilai koefisien regresi sebesar 0.109967 dengan nilai prob. sebesar 0.5915 Karena niai prob. lebih besar dari 0.05 , maka secara parsial variabel LDR berpengaruh positif dan tidak signifikan terhadap tingkat suku bunga deposito berjangka, hal ini berarti bahwa $\mathrm{Ha} 2$ ditolak.

c. Uji hipotesis 3

Hasil pengujian variabel ROA menunjukkan bahwa diperoleh nilai koefisien regresi sebesar -10.63718 dengan nilai prob. sebesar 0.4255 . Karena nilai prob.lebih besar dari 0.05 maka secara parsial variabel ROA berpengaruh negatif dan tidak signifikan terhadap tingkat suku bunga deposito berjangka,hal ini berarti bahwa $\mathrm{Ha} 3$ ditolak.
2. Hasil Uji Simultan (Uji F)

Tabel 4.11 Hasil Uji F

\begin{tabular}{|c|c|c|c|}
\hline S.E. of regression & Sum squared resid & F statistic & Prob (F-Statistc) \\
\hline 0.916816 & 1.681104 & 1.478225 & 0.300476 \\
\hline
\end{tabular}

Berdasarkan hasil uji $\mathrm{F}$ pada tabel diatas, diperoleh nilai probabilitas sebesar 0.300476 Karena probabilitas lebih besar dari 0.05, dengan demikian maka Ha4 ditolak. Dengan kata lain CAR, LDR dan ROA secara bersamasama tidak berpengaruh signifikan terhadap tingkat suku bunga deposito berjangka.

3. Hasil Uji Koefisien Determinasi

Tabel 4.12 Hasil Uji Koefisien Determinasi

\begin{tabular}{|c|}
\hline R-squared \\
\hline 0.788016 \\
\hline
\end{tabular}

Sumber : Data Sekunder Diolah 2015

Berdasarkan tabel diatas diperoleh nilai koefisien determinasi sebesar 0.788016 Hal ini menunjukkan bahwa variabel CAR, LDR dan ROA mampu menjelaskan terhadap variabel suku bunga deposito sebesar $78.8016 \%$ dan sisanya dijelaskan oleh variabel lainnya sebesar $21.1984 \%$.

\section{Pembahasan}

1. Pengaruh CAR terhadap tingkat suku bunga deposito berjangka

Berdasarkan hasil penelitian yang dilakukan, diketahui bahwa variabel CAR berpengaruh negatif dan tidak signifikan terhadap tingkat suku bunga deposito berjangka yang ditunjukkan dengan nilai koefisien regresi sebesar 0.674775 dengan nilai prob. sebesar 0.5915 . Hasil penelitian ini tidak sesuai dengan hipotesis dan di dukung oleh hasil penelitian dari Setyawan (2013) yang menunjukkan bahwa CAR tidak terbukti berpengaruh negatif dan signifikan terhadap tingkat suku bunga 
deposito berjangka. Semakin tinggi CAR maka semakin kuat kemampuan bank tersebut untuk menanggung risiko dari setiap kredit atau aktiva produktif yang berisiko. Atau dengan kata lain, maka semakin tinggi kecukupan modalnya untuk menanggung risiko kredit macetnya, sehingga kinerja bank semakin baik, dan dapat meningkatkan kepercayaan masyarakat terhadap bank. Dengan meningkatnya kepercayaan masyarakat terhadap bank, maka bank cenderung akan menurunkan tingkat suku bunga depositonya untuk mengurangi beban bunganya dan pada saat yang53 sama bank juga tidak perlu khawatir kehilangan nasabah karena tingginya kepercayaan masyarakat terhadap bank tersebut.

2. Pengaruh LDR terhadap tingkat suku bunga deposito berjangka

Berdasarkan hasil penelitian yang dilakukan dapat diketahui bahwa hipotesis ditolak. Pengujian terhadap variabel LDR menunjukkan variabel LDR berpengaruh positif dan tidak signifikan yang ditunjukkan dengan nilai koefisien regresi sebesar 0.109967 dengan nilai prob. 0.6871. Dari hasil penelitian tersebut dapat diartikan apabila LDR semakin tinggi maka tingkat suku bunga deposito akan semakin rendah. Nilai LDR yang tinggi menunjukkan bahwa penyaluran kredit yang dilakukan oleh bank lebih tinggi dibandingkan dengan dana yang diterima dari masyarakat. Dengan semakin besarnya penyaluran kredit maka pendapatan yang diterima bank dari pendapatan bunga kredit semakin besar oleh karena itu keuntungan yang diperoleh oleh bank juga semakin meningkat. Apabila bank menahan sebagian dari keuntungan untuk menambah cadangan dan memperkuat permodalan maka bank tidak perlu lagi menarik modal dari masyarakat dalam jumlah yang besar sehingga bank akan cenderung menurunkan tingkat suku bunga deposito berjangka.

3. Pengaruh ROA terhadap tingkat suku bunga deposito

Berdasarkan hasil penelitian yang dilakukan,diketahui bahwa variabel ROA berpengaruh negatif dan tidak signifikan terhadap tingkat suku bunga deposito berjangka yang ditunjukkan dengan nilai koefisien54 regresi 10.63718 dengan nilai prob. 0.4255 . Hasil penelitan ini tidak sesuai dengan hipotesis dan didukung oleh hasil penelitian dari Setyawan (2013) yang menunjukkan bahwa ROA merupakan rasio yang menggambarkan kemampuan bank dalam menghasilkan laba bersih berdasarkan tingkat asset tertentu. Semakin besar ROA maka semakin besar pula laba yang diperoleh oleh suatu bank. Apabila bank menentukan porsi laba ditahan yang besar, hal ini akan menambah modal sendiri yang di miliki oleh bank dengan konsekuensi setoran dividen yang diberikan kepada pemilik bank berkurang. Dengan demikian bank tidak harus terobsesi untuk menghimpun dana dari masyarakat dalam jumlah besar. Sehingga bank akan meringankan tingkat suku bunga deposito berjangka.

4. Pengaruh CAR, LDR dan ROA terhadap tingkat suku bunga deposito berjangka

Berdasarkan hasil uji $\mathrm{F}$ pada penelitian yang dilakukan, diperoleh nilai probabilitas sebesar 0.300476 . Karena probabilitas lebih besar dari 0.05 dapat diketahui bahwa variabel CAR, LDR dan ROA secara bersamasama tidak mempunyai pengaruh yang signifikan terhadap tingkat suku bunga deposito berjangka. Dengan demikian dapat diketahui bahwa rasio keuangan CAR, LDR, dan ROA tidak dapat digunakan untuk memprediksi tingkat suku bunga deposito berjangka. 
KESIMPULAN DAN SARAN

\section{Kesimpulan}

Penelitian ini dilakukan dengan tujuan untuk mengetahui pengaruh antara capital adequacy ratio (CAR), loan to deposit ratio (LDR) dan return on assets (ROA) terhadap tingkat suku bunga deposito berjangka pada bank BUMN di Indonesia periode 2009-2014. Berdasarkan hasil penelitian dan pembahasan pada penelitian ini, maka dapat ditarik kesimpulan sebagai berikut :

1. Variabel CAR berpengaruh negatif dan tidak signifikan terhadap tingkat suku bunga deposito berjangka sehingga $\mathrm{Ha} 1$ ditolak.

2. Variabel LDR berpengaruh positif dan tidak signifikan terhadap tingkat suku bunga berjangka sehingga $\mathrm{Ha} 2$ ditolak.

3. Variabel ROA berpengaruh negatif dan tidak signifikan terhadap tingkat suku bunga deposito berjangka sehingga $\mathrm{Ha} 3$ ditolak.

4. Secara simultan, variabel CAR, LDR dan ROA tidak berpengaruh terhadap tingkat suku bunga deposito berjangka sehingga Ha4 ditolak.

\section{Saran}

1. Bank BUMN sebaiknya memperhatikan rasio keuangan perusahaan dalam penetapan tingkat suku bunga deposito berjangka.

2. Penelitian selanjutnya sebaiknya dilakukan penambahan variabel independen demi keakuratan hasil penelitian.

3. Penelitian selanjutnya diharapkan menambah jumlah sampel bank sehingga penelitian yang dilakukan dapat lebih menyeluruh.

\section{DAFTAR PUSTAKA}

Budisantoso, Totok dan Nuritomo, 2014. Bank \& Lembaga Keuangan Lain. Jakarta: Salemba Empat.

Dendawijaya, Lukman. 2009. Manajemen Perbankan. Edisi Kedua. Jakarta: Ghalia Indonesia.

Dewi, May Karlina. 2012. Analisis Pengaruh Capital Adequacy Ratio (CAR), Loan to Deposit Ratio (LDR), Return on Assets (ROA) Terhadap Tingkat Suku Bunga Deposito Berjangka (Pada Bank Central Asia, Tbk Tahun 20012010). Skripsi. Makasar: Universitas Hassanudin.

Ismanto, Deni dan Desta Rizki Kusuma. 2012. Petunjuk Praktikum Eviews. Yogyakarta: FE UAD.

Kuncoro, Mudrajad dan Suhardjono. 2002. Manajemen Perbankan. Edisi Pertama. Yogyakarta: BPFE

Lestari, Sosie. 2008. Pengaruh Capital Adequacy Ratio, Return on Assets dan Loan to Deposit Ratio Terhadap Suku Bunga Deposito Berjangka Pada Bank BUMN di Indonesia Periode 2002-2006. Skripsi. Yogyakarta.

Martono. 2010. Bank dan Lembaga Keuangan Lainnya. Edisi II.Yogyakarta: Ekonisia

Nugroho,Yohanes Yuni Eko. 2010. Analisis Faktor-Faktor yang Mempengaruhi Tingkat Suku Bunga Deposito Berjangka Pada Bank Umum di Indonesia Tahun 20062008. Skripsi. Semarang: Universitas Diponegoro.

Rivai, Veithzal, Andria Permata Veithzal dan Ferry N. Idroes. 2007. Bank and 
Financial Institution Management. Jakarta: RajaGrafindo Persada.

Sanusi, Anwar. 2011. Metodologi Penelitian Bisnis. Jakarta: Salemba Empat.

Suliyanto. 2008. Teknik Proyeksi Bisnis. Yogyakarta: ANDI.

Suyatno, Thomas, Djuhaepah T. Marala, Azhar Abdullah, Johan Thomas Aonno, Tinon Yunianti Ananda, dan Chalik. 2005. Kelembagaan Perbankan. Edisi Ketiga. Jakarta: PT Gramedia Pustaka Utama.

Setiawan, Prastyo. 2013. Pengaruh Capital Adequacy Ratio (CAR), Loan to Deposit Ratio (LDR) dan Return on Assets (ROA) terhadap tingkat suku bunga deposito berjangka pada bank BUMN periode 2002-2012. Skripsi. Yogyakarta: UAD.

Taswan. 2010. Manajemen Perbankan. Edisi Kedua. Yogyakarta: UPP STIM YKPN. 